\title{
PENGARUH ORANG TUA TERHADAP MINAT MAHASISWA MENJADI GURU
}

\author{
Alinurdin dan Yayuk Muji Rahayu \\ Fakultas Keguruan dan Ilmu Pendidikan, Universitas Pamulang \\ alinurdin57ali@yahoo.com
}

\begin{abstract}
Abstrak
Tujuan utama penelitian ini adalah untuk menganalisis data secara empiris tentang pengaruh orang tua terhadap minat mahasiswa menjadi guru. Sampel pada penelitian ini adalah mahasiswa Program Studi Pendidikan Pancasila dan Kewarganegaraan angkatan ke-sepuluh Fakultas Keguruan dan Ilmu Pendidikan, Universitas Pamulang. Untuk menjawab masalah penelitian ini digunakan metode penelitian kuantitatif dengan teknik survey dan instrumen penelitian berupa angket. Pengujian hipotesis dilakukan dengan cara mencari ada atau tidaknya hubungan antar variabel dan juga besarnya variabel bebas (variabel X) mempengaruhi variabel terikat (variabel $Y$ ). Berdasarkan hasil penelitian diperoleh besarnya nilai koefisien korelasi $(r)$ sebesar 0,389, dimana besarnya $r$ adalah lebih besar dari nilai $r$ tabel $(0,195)$, menunjukkan bahwa terdapat hubungan antara variabel pengaruh orang tua dan minat menjadi guru. Pengaruh positif dan signifikan antara kedua variabel ini ditunjukkan oleh besarnya nilai t hitung yaitu sebesar 5,08 sedangkan nilai t tabel adalah 1,98. Besarnya pengaruh ditunjukkan oleh besarnya koefisien determinasi (KD) yaitu sebesar 15,164 $\%$, yang artinya bahwa Orang Tua mempengaruhi minat menjadi guru. sebesar $15,164 \%$.
\end{abstract}

Kata Kunci: Pengaruh orang tua, minat menjadi guru.

\footnotetext{
Jurnal Pendidikan Kewarganegaraan

Journal of Civics and Education Studies

The journal is published by Department of Civic Education

Faculty of Teacher Training and Education

Universitas Pamulang - Indonesia
}

Copyright $\odot 2017 \mid$ ISSN: 2302-0865 


\section{PENDAHULUAN}

Keluarga mempunyai peranan yang cukup besar dalam memberikan pengetahuan, informasi bagi siswa untuk menumbuhkan minat menjadi guru, karena dalam lingkungan keluarga inilah seseorang pertama kali mendapatkan pendidikan, bimbingan, asuhan, pembiasaan, dan isi serta cara-cara pendidikan. Di dalam keluarga akan selalu mempengaruhi tumbuh dan berkembangnya watak, budi pekerti dan kepribadian tiap-tiap manusia. Keluarga terutama orang tua mempunyai peran yang cukup penting dan cukup berpengaruh terhadap anaknya termasuk dalam hal memilih pekerjaan atau profesi yang akan dipilih, dan di lingkungan keluarga inilah anak akan mendapatkan informasi tentang karier pekerjaan di masa yang akan datang.

Pada kenyataannya banyak orang tua yang beranggapan bahwa profesi guru terutama guru bukan sebuah profesi yang menjanjikan, dilihat dari segi materi atau penghasilan seorang guru yang masih rendah. Sehingga kebanyakan orang tua tidak mengarahkan anak-anaknya untuk memilih profesi guru yang kemudian berdampak pada masih kurang diminatinya profesi guru di kalangan siswa pada jenjanga pendidikan menengah. Banyak orang tua menilai bahwa status pekerjaan masih dianggap menjadi tolok ukur tingkat keberadaan dan keberhasilan seseorang. Termasuk juga status pekerjaan sebagai seorang guru, masih dianggap sebagai status yang kurang elite dimata orang tua. Mereka menganggap bahwa pekerjaan sebagai dokter, hakim, pengacara, akuntan, arsitek dan yang lainnya merupakan pekerjaan yang lebih menjanjikan dari pada menjadi seorang guru. Padahal apabila dilihat secara lebih mendalam profesi guru merupakan profesi yang mulia karena dari profesi inilah akan lahir sumber daya manusia yang berkualitas. Konotasi digugu dan ditiru akan bisa memberikan tempat tersendiri bagi penyandangnya di mata masyarakat.

Fakultas Keguruan dan Ilmu Pendidikan Universitas Pamulang yang akan menghasilkan calon-calon tenaga pendidik yang profesional, maka dapat diasumsikan bahwa mahasiswa Fakultas Keguruan dan Ilmu Pendidikan Universitas Pamulang khususnya Prodi PPKn mempunyai minat yang tinggi untuk menjadi calon tenaga pendidik yang profesional. Namun dari perbincangan sehari-hari di kampus, tidak sedikit mahasiswa yang terpaksa kuliah di FKIP karena mengikuti keinginan orang tua. Kondisi inilah yang mendorong peneliti untuk mengkaji secara lebih mendalam faktor-faktor penyebabnya, baik itu faktor internal maupun eksternal siswa. Oleh karena itu yang menjadi permasalahan penelitian ini dirumuskan "apakah terdapat pengaruh positif dan signifikan antara pengaruh Orang tua terhadap minat menjadi guru Pendidikan Pancasila dan Kewarganegaraan?

Sebagai landasan teori dalam melakukan penelitian, terlebih dahulu diuraikan beberapa teori yang berhubungan dengan orang tua (variabel $\mathrm{X}$ ) dan minat menjadi guru (variabel $\mathrm{Y}$ ). 
Dalam penyajiannya terlebih dahulu kami uraikan tentang variabel $Y$. Minat merupakan sumber motivasi yang mendorong individu untuk melakukan apa yang mereka inginkan. Menurut Slameto (2015:80), "minat adalah rasa suka dan rasa ketertarikan pada suatu hal atau aktivitas, tanpa ada yang menyuruh. Minat pada dasarnya adalah penerimaan akan suatu hubungan antara diri sendiri dengan sesuatu di luar diri". Pendapat lain dari Syah sebagaimana dikutif oleh Tri Nuryani (2014:86), “minat (interest) berarti kecenderungan dan kegairahan yang tinggi atau keinginan yang besar terhadap sesuatu". Menurut Walgito sebagaimana dikutif oleh Anafitrah Sari (2013:38), “minat adalah suatu keadaan dimana seseorang mempunyai perhatian terhadap suatu hal dengan disertai suatu keinginan untuk mengetahui dan mempelajari maupun membuktikannya lebih lanjut". Sedangkan menurut Djaali sebagaimana dikutif oleh Dalyono (2015:121), "minat adalah rasa lebih suka dan rasa ketertarikan pada suatu hal atau aktivitas, tanpa ada yang menyuruh. Minat pada dasarnya adalah penerimaan akan suatu hubungan antara diri sendiri dengan sesuatu di luar diri”. Menurut Hurlocksebagaimana dikutif oleh Wakid (2014:74), “minat merupakan sumber motivasi yang mendorong orang untuk melakukan apa saja yang mereka inginkan bila mereka bebas memilih". Berdasarkan pada beberapa pendapat mengenai minat di atas maka dapat diambil kesimpulan bahwa minat adalah suatu keadaan dimana seseorang mempunyai perhatian yang lebih terhadap sesuatu hal yang diikuti dengan keinginan dan rasa suka yang tinggi untuk mengetahui, mempelajari, memiliki dan melakukannya.

Sementara itu Hurlock membagi minat ke dalam empat aspek, sebagaimana dikutif oleh Wakid (2014:27), minat terbagi menjadi tiga aspek, yaitu : 1) aspek kognitif, adalah minat yang didasarkan pada pengalaman pribadi dan hal yang pernah dipelajari baik di rumah, sekolah dan masyarakat serta berbagai jenis media massa, 2) aspek afektif, merupakan konsep yang membangun aspek kognitif, minat dinyatakan dalam sikap terhadap kegiatan yang ditimbulkan dan berkembang berdasarkan pengalaman pribadi dari sikap orang yang penting yaitu orang tua, guru dan teman sebaya terhadap kegiatan yang berkaitan dengan minat tersebut dan dari sikap yang dinyatakan atau tersirat dalam berbagai bentuk media massa terhadap kegiatan itu. 3) aspek psikomotor, pada aspek ini minat berjalan dengan lancar tanpa perlu pemikiran lagi dan dengan urutan yang tepat.

Selanjutnya Muhibbin (2005 : 136), "Minat (interest) berarti kecenderungan dan kegairahan yang tinggi atau keinginan yang besar terhadap sesuatu". Berbeda dengan Muhibbin, menurut Slameto (2015:80), "Minat adalah rasa suka dan rasa ketertarikan pada suatu hal atau aktivitas, tanpa ada yang menyuruh". Minat pada dasarnya adalah penerimaan akan suatu hubungan antara diri sendiri dengan sesuatu di luar diri. Semakin kuat atau dekat hubungan tersebut, maka akan semakin besar minat dalam diri seseorang. 
Sedangkan Sadirman sebagaimana dikutif oleh Wakid (2014: 76) minat diartikan sebagai, "Suatu kondisi yang terjadi apabila seseorang melihat ciri-ciri atau arti sementara situasi yang dihubungkan dengan keinginan-keinginan atau kebutuhan-kebutuhannya sendiri, oleh karena itu apa yang dilihat seseorang sudah tentu akan membangkitkan minatnya sejauh apa yang dilihat itu mempunyai hubungan dengan kepentingannya sendiri”. Sedangkan menurut Anafitrah Sari (2013: 38), "Minat sangat mempengaruhi kepribadian seseorang bahkan sampai mempengaruhi tingkah laku seseorang, tapi dengan adanya hal ini dapat mendorong orang untuk tetap melakukan dan memperoleh sesuatu yang diinginkannya".

Berdasarkan teori di atas maka dapat disimpulkan bahwa minat terdiri dari beberapa unsur yaitu unsur kognisi yang artinya bahwa minat didahului oleh rasa ingin tahu yang tinggi yang mendorong seseorang untuk mempelajari dan mengetahui lebih jauh tentang hal tersebut, unsur emosi yaitu adanya rasa senang dan suka terhadap hal yang dipelajari dan diketahuinya. Minat akan timbul karena adanya rasa ketertarikan seseorang terhadap suatu hal dan adanya rasa ingin untuk memperoleh serta adanya harapan untuk mencapainya. Minat adalah sumber motivasi yang muncul secara spontan, wajar dan selektif yang akan mengarahkan tindakan seseorang terhadap suatu objek yang dia sukai yang kemudian orang tersebut menyukai serta mnyenangi objek yang dituju.
Selanjutnya mengenai guru, guru adalah sebuah profesi yang sangat mulia, kehadiran guru bagi peserta didik ibarat sebuah lilin yang menjadi penerang tanpa batas tanpa membedakan siapa yang diteranginya, demikian pula terhadap peserta didik. Tetapi dalam mengemban amanah sebagai seorang guru, perlu kiranya tampil sebagai sosok profesional. Sosok yang memiliki ilmu pengetahuan dan wawasan, sosok yang dapat memberi contoh tauladan dan sosok yang selalu berusaha untuk maju, terdepan dan mengembangkan diri untuk mendapatkan inovasi yang bermanfaat sebagai bahan pengajaran kepada anak didik.

Menurut Kamus Besar Bahasa indonesia sebagaimana dikutif oleh Wakid (2014: 45), "Guru adalah orang yang pekerjaannya (mata pencahariannya, profesinya) mengajar". Pengertian guru menurut Kamus Besar Bahasa Indonesia tersebut masih sangat umum dan belum bisa menggambarkan sosok guru yang sebenarnya, sehingga untuk memperjelas gambaran tentang seorang guru diperlukan definisi-definisi lain. Menurut Usman (2013: 70), "Guru adalah orang yang tugasnya terkait dengan upaya mencerdaskan kehidupan bangsa dalam semua aspeknya, baik spiritual dan emosional, intelektual, fisikal, maupun aspek lainnya". Menurut Ahmad Barizi \& Muhammad Idris sebagaimana dikutif oleh Wakid (2014 : 42), "Guru adalah orang yang pekerjaannya mengajar atau memberikan pelajaran di sekolah atau di dalam kelas".

Pendapat lain tentang guru dikemukakan oleh Syarifuddin Nurdin 
dan Sadirman, sebagaimana dikutif oleh Anafitrah (2013: 18), "Guru adalah seseorang yang mempunyai gagasan yang harus diwujudkan untuk kepentingan anak didik, menunjang hubungan sebaikbaiknya, dalam kerangka menjunjung tinggi, mengembangkan dan menerapkan keutamaan yang menyangkut agama, kebudayaan dan keilmuwan", sedangkan menurut Sadirman sebagaimana dikutif oleh Anafitrah (2013:15), “Guru merupakan salah satu komponen manusiawi dalam proses belajar mengajar yang ikut berperan dalam usaha pembentukan sumber daya manusia yang potensial di bidang pembangunan"

Berdasarkan pendapat-pendapat para ahli tersebut di atas dapat ditarik kesimpulan mengenai definisi guru. Guru adalah orang yang pekerjaannya mengajar dan ikut berperan serta dalam pembentukan sumber daya manusia yang potensial di bidang pembangunan, dimana gagasan-gagasan yang dimilikinya akan diwujudkan untuk kepentingan anak didik, mengembangkan dan menerapkan keutamaan yang menyangkut agama, kebudayaan dan keilmuan, serta berupaya mencerdaskan kehidupan bangsa dalam semua aspeknya, baik aspek spiritual dan emosional, fisikal maupun aspek-aspek lainnya.

Sementara itu Undang Undang Republik Indonesia No 14 Tahun 2005 tentang Guru dan Dosen, Bab I Pasal (1) menyatakan bahwa Guru adalah pendidik profesional dengan tugas utama mendidik, mengajar, membimbing, mengarahkan, melatih, menilai dan mengevaluasi peserta didik pada pendidikan anak usia dini jalur pendidikan formal, pendidikan dasar, dan pendidikan menengah. Profesional adalah pekerjaan atau kegiatan yang dilakukan oleh seseorang dan menjadi sumber penghasilan kehidupan yang memerlukan keahlian, kemahiran atau kecakapan yang memenuhi standar mutu atau norma tertentu serta memerlukan pendidikan profesi.

Berdasarkan pendapat-pendapat beberapa ahli di atas maka dapat ditarik kesimpulan bahwa guru adalah seseorang yang bertugas sebagai pengajar, berperan serta dalam pembentukan sumber daya manusia yang potensial di bidang pembangunan, dan berupaya mencerdaskan kehidupan bangsa dalam semua aspeknya, baik aspek spiritual dan emosional, fisikal maupun aspek-aspek lainnya. Guru adalah seseorang yang telah memperoleh surat keputusan (SK) baik dari pihak swasta maupun pemerintah untuk menggeluti profesi yang memerlukan keahlian khusus dalam tugas utamanya untuk mengajar dan mendidik siswa pada jalur formal, pendidikan dasar dan menengah yang tujuan utamanya untuk mencerdaskan bangsa dalam semua aspek.

Selanjutnya Menurut Kamus Besar Bahasa Indonesia (2005:849), "Pengaruh adalah daya yang ada atau timbul dari sesuatu (orang atau benda) yang ikut membentuk watak, kepercayaan atau perbuatan seseorang". Sementara itu Surakhmad ( dalam Wakid 2014 :27) menyatakan bahwa, "Pengaruh adalah kekuatan yang muncul dari suatu benda atau orang dan juga gejala alam yang dapat memberikan perubahan terhadap 
apa-apa yang di sekelilingnya". Jadi pengaruh adalah merupakan suatu daya atau kekuatan yang timbul dari sesuatu, baik itu orang maupun benda serta segala sesuatu yang ada di alam sehingga mempengaruhi apa-apa yang ada di sekitarnya. Pengaruh adalah hasil dari sikap yang dilakukan oleh seseorang atau kelompok dikarenakan seseorang atau kelompok tersebut telah melakukan dan menjalankan kewajibannya terhadap pihak yang meminta menjalankan kewajibannya tersebut.

Menurut Dedikbud (2001:845), "Pengaruh adalah daya yang ada atau timbul dari sesuatu (orang atau benda) yang ikut membentuk watak kepercayaan dan perbuatan seseorang". Sedangkan menurut WJS Poerwardarminta (dalam Anafitrah ,2013:31), “Pengaruh adalah daya yang ada atau timbul dari sesuatu, baik itu orang maupun benda dan sebagainya yang berkuasa atau berkekuatan dan berpengaruh terhadap orang lain". Dari kedua pendapat ini dapat disimpulkan bahwa pengaruh adalah sebagai suatu daya yang ada atau timbul dari suatu hal yang memiliki akibat atau hasil dan dampak yang ada.

Selanjutnya tentang pengeruh orang tua, Menurut M. Wiryanto (dalam Anafitrah 2013:31), "pengaruh merupakan tokoh formal maupun informal dalam masyarakat, mempunyai ciri lebih kosmopolitan, inovatif, kompeten, aksesible dibanding pihak yang dipengaruhi”. Sedangkan menurut Badudu dan Zain (dalam Wakid 2014:31), "pengaruh adalah daya yang menyebabkan sesuatu yang terjadi, sesuatu yang dapat membentuk atau mengubah sesuatu yang lain dan tunduk atau mengikuti karena kuasa atau kekuatan orang lain". Berbeda dengan M. Wiryanto dan Badudu, Scott dan Mitchell (dalam Tri Nuryani 2014:19) berpendapat bahwa "pengaruh adalah merupakan suatu transaksi sosial dimana seseorang atau kelompok orang digerakkan oleh orang atau sekelompok orang yang lainnya untuk melakukan kegiatan sesuai dengan harapan". Berdasarkan beberapa teori ini dapat ditarik kesimpulan bahwa pengaruh adalah suatu daya yang dilakukan oleh orang yang lebih mempunyai inovatif, kompeten, aksesible terhadap orang yang dipengaruhi tentang suatu kegiatan yang diinginkan sehingga menyebabkan orang yang dipengaruhi tersebut melakukan suatu kegiatan sesuai keinginan pihak yang mempengaruhi.

Berbicara tentang orang tua tentunya tidak dapat dipisahkan dari tempat orang tua dan anak. Orang tua dan anak hidup dalam satu unit yang disebut keluarga. Keluarga merupakan unit terkecil dari masyarakat. Dalam Kamus Besar Bahasa Indonesia (2005:802) pengertian orang tua adalah ayah ibu kandung, orang yang dianggap tua (cerdik pandai, ahli, dsb). Sejalan dengan pendapat tersebut, Soelaeman (1994:179) mengemukakan, “.. istilah orang tua hendaknya tidak pertama-tama diartikan sebagai orang yang tua, melainkan sebagai orang yang dituakan, karenanya diberi tanggung jawab untuk merawat dan mendidik anaknya menjadi manusia derwasa".

Sedangkan menurut Langgulung (sebagaimana dikutif oleh wakid 2014 
:26) yang menjelaskan bahwa, "Islam memandang orang tua (keluarga) sebagai lingkungan pertama bagi individu merubah banyak kemungkinankemungkinan, kesanggupan-kesanggupan dan kesediaannya menjadi kenyataan yang hidup dan tingkah laku yang nampak". Hal ini dijelaskan pula oleh Darajat (dalam Helmawaty, 2014:39) bahwa : "Orang tua adalah pembina atau pendidik pribadi yang pertama dalam hidup. Kepribadian orang tua, sikp dan cara hidup mereka merupakan unsur-unsur pendidikan yang tidak langsung, dengan sendirinya akan masuk $\mathrm{kr}$ dalam pribadi anak yang sedang tumbuh dan berkembang“.

Berdasarkan definisi-definisi tentang orang tua di atas, maka dapat disimpulkan bahwa orang tua adalah dua orang dewasa yang hidup bersama dalam ikatan perkawinan yang telah melahirkan anak atau keturunan, yaitu Ibu-Bapak, yang mempunyai tanggung jawab untuk membina anak-anak untuk diberikan pendidikan, kasih sayang. Selain itu , dan kebutuhan lainnya agar kelak anak tersebut menjadi manusia dewasa dan warga negara yang bertanggung jawab, disiplin, dan bergaul dengan baik dalam masyarakat, juga membimbing anaknya dengan cera memberikan contoh yang baik dalam menjalani kehidupan seharihari.

Selain itu orang tua juga telah memperkenalkan anaknya kedalam hal-hal yang terdapat di dunia ini dan menjawab secara jelas tentang sesuatu yang tidak dimengerti oleh anak. Maka pengetahuan yang pertama diterima oleh anak adalah dari orang tuanya. Dan orang tua juga adalah sebagai lingkungan pertama dari individu-individu untuk berinteraksi terutama bagi anak-anak untuk memperoleh akhlak atau moral serta kebiasaan-kebiasaan yang baik, dan juga orang tua sebagai pembina pribadi yang pertama bagi anaknya.

Dalam menjalankan tugasnya orang tua mempunyai peran dan fungsi yang sangat penting dala $\mathrm{m}$ kehidupan anak. Peranan diartikan sebagai, "tindakan yang dilakukan oleh seseorang dalam suatu peristiwa" (Kamus Besar Bahasa Indonesia, 2005:854). Sedangkan menurut Soekanto (1990: 268-269), “peranan merupakan aspek dinamis kedudukan (status), apabila seseorang melaksanakan hak dan kewajibannya sesuai dengan kedudukannya maka dia menjalankan suatu peranan". Peranan mecakup tiga hal yaitu :1)peranan meliputi norma-norma yang dihubungkan dengan posisi atau tempat seseorang dalam masyarakat. Peranan dalam arti ini merupakanrangkaian peraturan-peraturan yang membimbing seseorang dalam kehidupan kemasyarakatan, 2) peranan adalah suatu konsep tentang apa yang dapat dilakukan oleh individu dalam masyarakat sebagai organisasi, 3) peranan juga dapat dikatakan sebagai perilaku individu yang penting bagi struktur sosial masyarakat.

Dari beberapa pengertian tentang peranan di atas dapat disimpulkan bahwa peranan adalah kedudukan seseorang dalam menempatkan diri sebagai orang yang melakukan tindakan dalam suatu peristiwa. Dalam penelitian ini peranan 
yang dimaksud adalah peranan orang tua. Peranan orang tua berarti berbagai hak dan wewenang serta kewajiban orang tua dalam menjalankan perannya dalam keluarga bagi anaknya dalam membina dan membimbing anaknya dalam keluarga, masyarakat, bangsa dan negara.

Sejalan dengan peranan orang tua, Soelaeman (1994:

mengemukakan delapan fungsi keluarga yng harus dilakukan oleh orang tua, yaitu : 1) fungsi edukasi, adalah fungsi keluarga yang berkaitan denganmasalah pendidikan anak khususnya serta pembinaan anggota keluarga pada umumnya, 2) fungsi sosialisasi, adalah fungsi yang berkaitan denganmempersiapkan anak untuk menjadi anggota masyarakat yang baik, dalam hal ini keluarga berperan sebagai penghubung antara kehidupan anak dan kehidupan sosial dan norma sosial sehingga kehidupan di sekitarnya dapat dimengerti oleh anak, dan pada gilirannya anak dapat berpikir dan berbuat positif di dalam dan terhadap lingkungannya, 3) fungsi proteksi (perlindungan), adalah untuk menjaga dan memelihara anak serta anggota keluarga lainnya dari tindakan negatif yang mungkin timbul, baik dari dalam maupun dari luar kehidupan keluarga, 4) fungsi afeksi, adalah bahwa di dalam komunitasnya dengan orang tua maupun dengan lingkungannya anak tidak saja menggunakan mata dan telinga akan tetapi juga dengan perasaannya, 5) fungsi religius, berkaitan dengan kewajiban orang tua untuk mengenalkan, membimbing, memberi teladan dan melibatkan anak serta anggota keluarga lainnya kemgenai kaidah-kaidah agama dan perilaku keagamaan, 6) fungsi ekonomis, menunjukkan bahwa keluarga merupakan kesatuan ekonomis berkaitan dengan pencarian nafkah, pembinaan usaha dan perencanaan anggaran biaya, baik penerimaan maupun pengeluaran biaya keluarga, 7) fungsi rekreasi, diwujudkan melalui penciptaan suasana kehidupan yang tenang dan harmonis di dalam keluarga, 8) fungsi biologis, berhubungan dengan pemenuhan kebutuhan-kebutuhan biologis keluarga.

Berdasarkan beberapa penjelasan tentang peranan orang tua di atas dapat disimpulkan bahwa dalam melaksanakan perannya para orang tua melaksanakan berbagai fungsi. Sudah barang tentu dalam pelaksanaan fungsi tersebut sangat tergantung pada situasi dan kondisi keluarga masing-masing. Karena setiap keluarga mempunyai perbedaan dalam kehidupan masyarakat. Dan jelas pula bahwa keluarga merupakan tempat anak memperoleh ketenangan, ketrentaman, perlindungan, masa depan dan sebagainya.

Selain peran dan fungsinya, pola asuh orang tua juga ikut menentukan masa depan dan profesi anak. Menurut Kamus Besar Bahasa Indonesia (2005:885), "pola berarti sistem, cara kerja sedangkan asuh (2005:73) berarti membimbing (membantu, melatih, dsb) supaya dapat berdiri sendiri". Dalam penelitian ini pola asuh yang dimaksud adalah pola asuh orang tua. Menurut Syaodih (1999:9) dalam Tarigan (2008:22), "pola asuh orang tua adalah suatu bentuk kegiatan merawat memelihara dan membimbing yang dilakukan orang tua kepada anaknya 
agar dapat mandiri, tumbuh dan berkembang secara sehat dan optimal".

Sebelum penelitian ini dilakukan, terdapat beberapa penelitian serupa yang telah dilakukan, antara lain sebagai berikut:

Pengaruh Lingkungan Keluarga Terhadap Minat Menjadi Guru Akutansi pada Mahasiswa Program Studi Pendidikan Akutansi Angkatan 2010 Universitas Negeri Yogyakarta, tahun 2014, peneliti Dewi Ayuni Rahmawati. Hasil penelitian terdapat pengaruh positif lingkungan keluarga terhadap minat menjadi guru pada mahasiswa program studi Pendidikan akutansi angkatan 2010 UNY. Hasil perhitungan koefisien korelasi (r) sebesar 0,322 dan koefisien determinasi (KD) sebesar 10,37\%, hasil t hitung sebesar 2,806 lebih besar dari $\mathrm{t}$ tabel pada taraf signifikansi $5 \%$ yaitu sebesar 1,980 .

Pengaruh Lingkungan Keluarga dan Persepsi Mahasiswa tentang Profesionalisme Guru terhadap Minat Mahasiswa menjadi Guru pada MahasiswaProgram Studi Pendidikan Ekonomi FKIP Universitas Negeri Surakarta tahun 2014, peneliti Wakid Nur Dianto. Lingkungan keluarga berpengaruh positip terhadap minat menjadi guru yang ditunjukkan dengan nilai $r=0,611$ dan koefisien determinasi (KD) sebesar $37,33 \% \quad t_{\text {hitung } 8,447}>t_{\text {tabel }} 1,658$ pada taraf signifikansi $5 \%$.

Dari kajian teoretik sebagaimana uraian di atas, peneliti menduga terdapat pengaruh positif dan signifikan antara pengaruh orang tua terhadap minat menjadi guru bagi mahasiswa PPKn Universitas Pamulang.

\section{METODOLOGI PENELITIAN}

Penelitian ini bertujuan untuk menganalisi data secara empiris mengenai pengaruh orang tua terhadap minat menjadi guru pada mahasiswa Program Studi Pendidikan Pancasila dan Kewarganegaraan Fakultas Keguruan dan Ilmu Pendidikan Universitas Pamulang. Sedangkan tempat penelitian yaitu pada Program Studi Pendidikan Pancasila dan Kewarganegaraan Fakultas Keguruan dan Ilmu Pendidikan Universitas Pamulang, yang beralamat di Jl. Surya Kencana No 1 Pamulang, Tangerang Selatan, Banten. Adapun waktu pelaksanaannya kurang lebih tiga bulan terhitung dari bulan Juni sampai dengan bulan Agustus 2016.

$\begin{array}{cllr}\text { Metode } & \text { yang digunakan pada } \\ \text { penelitian } & \text { ini } & \text { adalah dengan }\end{array}$ menggunakan metode kuantitatif. Metode penelitian kuantitatif adalah metode penelitian yang berlandaskan pada filsafat positivisme, digunakan untuk meneliti pada populasi atau sampel tertentu (Sugiyono, 2014:7) Metode penelitian kuantitatif digunakan untuk memecahkan masalah dengan cara menggambarkan keadaan objek penelitian pada saat keadaan sekarang berdasarkan kondisi riil yang dinyatakan dalam bentuk angka-angka, kemudian dianalisis selanjutnya dapat ditarik kesimpulan. Populasi penelitian mahasiswa angkatan ke sepuluh (10) Program Studi Pendidikan Pancasila dan Kewarganegaan, Fakultas Keguruan dan Ilmu Pendidikan 
Jurnal Pendidikan Kewarganegaraan, Vol. 4, No. 1, Maret 2017
Available online at http://openjournal.unpam.ac.id/index.php/PKn
Universitas Pamulang berjumlah 145 Mahasiswa. Sedangkan sampel yang diambil berdasarkan rumusl solvin dilakukan secara acak dan proporsional berjumlah 106.

Alat ukur yang digunakan berupa pertanyaan yang diajukan dalam skala sikap dan perilaku, ada dua kategori yaitu pertanyaan positif dan pertanyaan negatif. Jawaban dari pernyataan dalam penelitian ini disajikan dalam bentuk skala Likert dengan lima kategori jawaban, yaitu ungkapan pada variabel Pengaruh Orang tua dan Minat menjadi Guru, yaitu Sangat Setuju (SS), Setuju (S), Ragu-ragu (RG),
Tidak Setuju (TS) dan Sangat Tidak Setuju (STS).

\section{HASIL DAN PEMBAHASAN}

Hasil peneltitian mengenai pengaruh orang tua diperoleh rentangan nilai sebesar 44, dengan skor tertinggi yaitu 129 dan skor terendah sebesar 85, banyaknya kelas ada 8 , dengan panjang interval kelas sebesar 6. Selain itu juga diperoleh skor rata-rata (mean) sebesar 110,05 , nilai tengah (median) sebesar 115,54, modus (mode) sebesar 106,21 dan simpangan baku atau standar deviasi sebesar

11,53 .

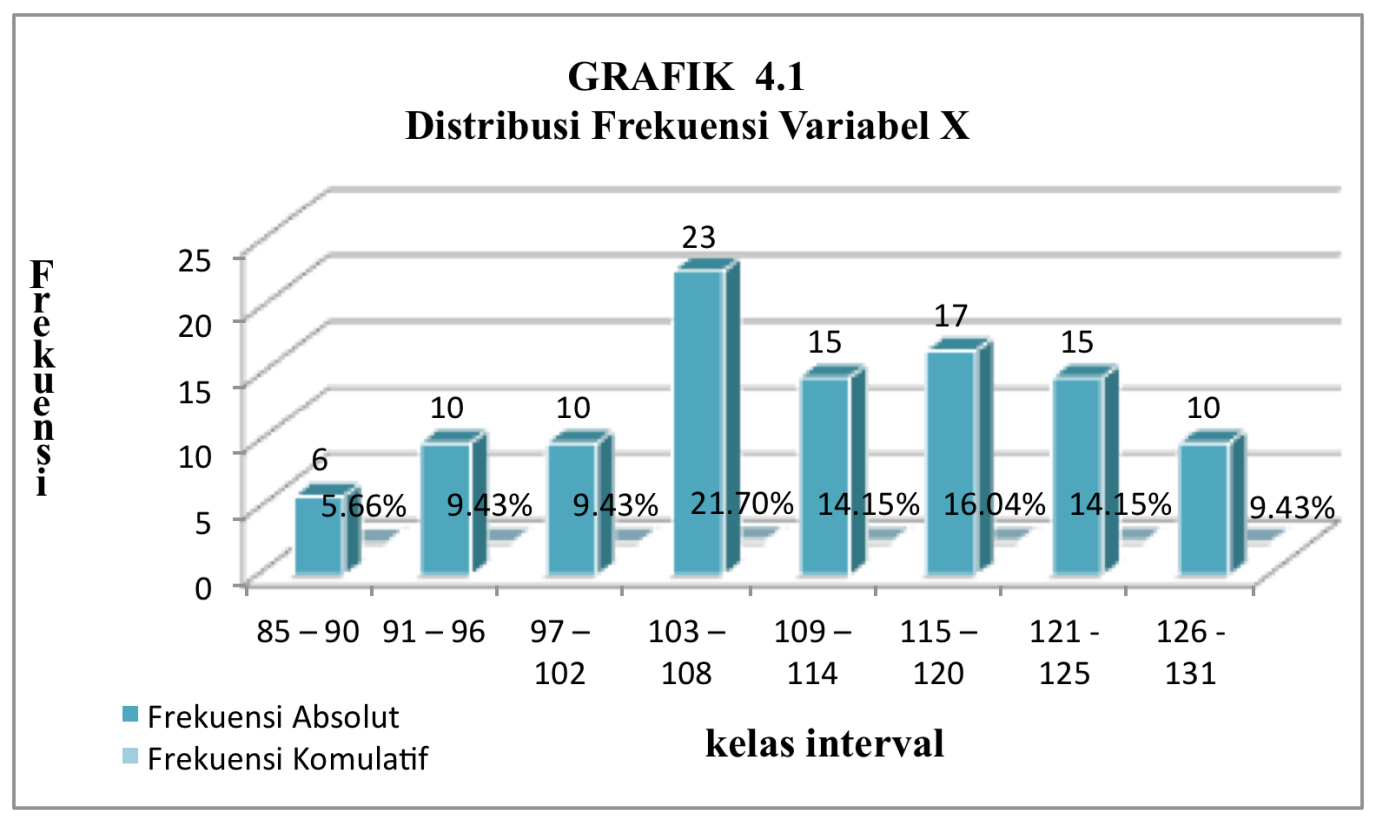

Dari grafik di atas dapat dilihat bahwa pengaruh orang tua pada Program Studi PPKn angkatan ke sepuluh yang tertinggi terletak antara kelas interval 103 - 108, dengan frekuensi komulative sebesar $21,70 \%$. Dari 106 responden dapat diinterpretasikan dalam pengaruh orang tua kecenderungan sikap tertinggi terletak pada indikator ke tiga yaitu dukungan orang tua kepada anak. Karena dari 106 responden banyak responden yang memilih kecenderungan sikap indikator dukungan orang tua kepada anak yakni no 20 sampai dengan 25, dengan kategori sering dan selalu. 
Data tentang minat menjadi guru dapat diperoleh dari instrumen yang digunakan dalam penelitian ini. Berdasarkan data penelitian diperoleh rentangan nilai sebesar 40, dengan skor tertinggi sebesar 125 dan skor terendah sebesar 85 , banyaknya kelas adalah 8 dengan panjang interval sebesar 6. Selain itu diperoleh juga skor rata-rata (mean) sebesar 110,54 dan nilai tengah (median ) sebesar 111, 38, nilai modus (mode) sebesar 113,83 dan simpangan baku atau standar deviasi (s) sebesar 9,11.

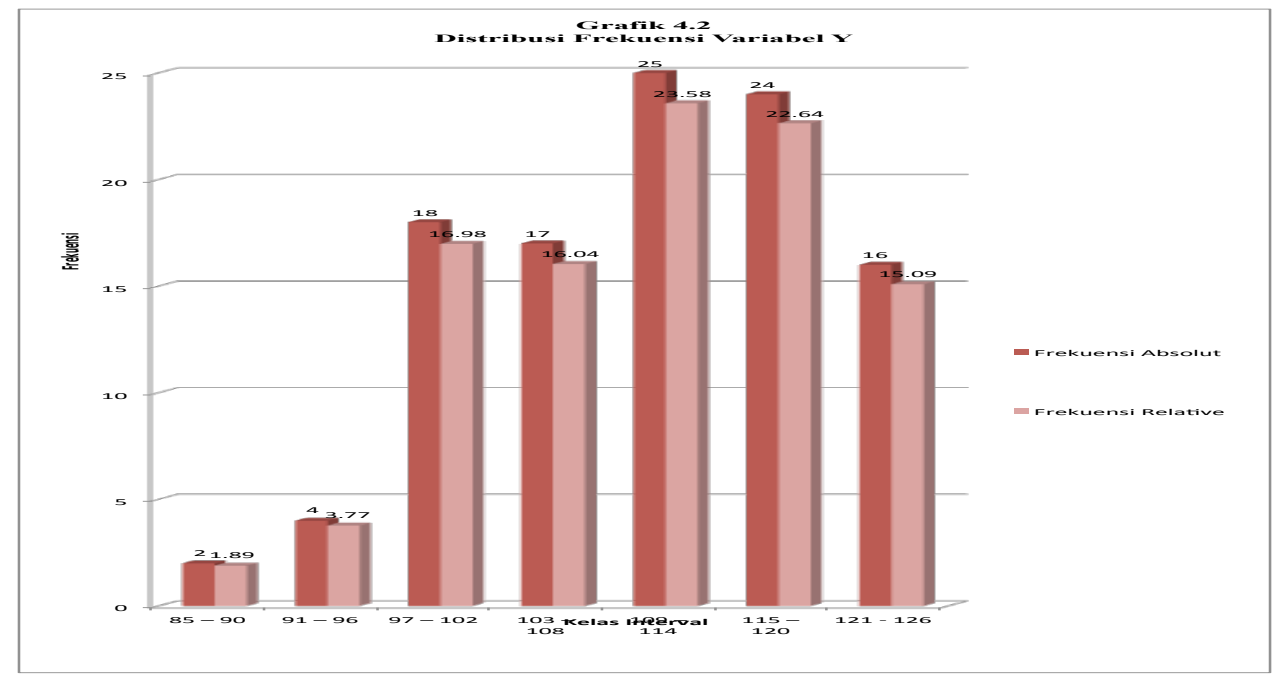

Dari grafik di atas dapat dilihat bahwa minat menjadi guru Pendidikan Pancasila dan Kewarganegaraan pada Program Studi Pendidikan Pancasila dan Kewarganegaraan angkatan ke sepuluh yang tertinggi terletak antara kelas Interval 109 - 114, dengan frekuensi relative sebesar $23,58 \%$. Dari 106 responden dapat diinterpretasikan dalam minat menjadi guru kecenderungan sikap tertinggi terletak pada indikator ke dua yaitu adanya rasa suka, ketertarikan dan perhatian yang lebih besar terhadap profesi guru Pendidikan Pancasila dan Kewarganegaraan. Karena dari 106 responden banyak responden yang memilih kecenderungan sikap indikator adanya rasa suka, ketertarikan dan perhatian yang lebih besar terhadap profesi guru, yakni no 10 sampai dengan 20, dengan kategori sering dan selalu.

Perhitungan dalam uji hipotesis dilakukan dengan terlebih dahulu menghitung korelasinya. Untuk menghitung korelasi antara pengaruh orang tua dan minat menjadi guru Pendidikan Pancasila dan Kewarganegaraan digunakan rumus Pearson Product Momen, yaitu

$$
\begin{gathered}
\mathrm{r}_{\mathrm{xy}}=\frac{n\left(\sum x y\right)-\left(\sum x \sum y\right)}{\sqrt{\left(n \sum x^{2}-\left(\sum x\right)^{2}\right)\left(n \sum y^{2}-\left(\sum y\right)^{2}\right)}} \\
=
\end{gathered}
$$

$\frac{(106 \times 1295597)-(11677 \times 11723)}{\sqrt{\left((106 \times 1299483)-(11677)^{2}\right.}\left((106 \times 130529)-(11723)^{2}\right.}$

$$
=0,389
$$


Uji Korelasi

\begin{tabular}{|l|l|l|l|l|}
\hline No. & \multicolumn{2}{|c|}{ Uji Korelasi } & \multicolumn{1}{c|}{ Kriteria } & \multicolumn{1}{c|}{ Kesimpulan } \\
\hline 1 & $\mathrm{~F}_{\text {hitung }}=1,41$ & $\mathrm{~F}_{\text {tabel }}=1,57$ & $\mathrm{~F}_{\text {hitung }}<\mathrm{F}_{\text {tabel }}$ & Regresi berpola linear \\
\hline 2 & $\mathrm{r}_{\text {hitung }}=0,389$ & $\mathrm{r}_{\text {tabel }}=0,195$ & $\mathrm{r}_{\text {hitung }}>\mathrm{r}_{\text {tabel }}$ & $\begin{array}{l}\text { Terdapat hubungan } \\
\text { antara variabel X dan } \\
\text { variabel } \mathrm{Y}\end{array}$ \\
\hline 3 & $\mathrm{t}_{\text {hitung }}=5,082$ & $\mathrm{t}_{\text {tabel }}=1,98$ & $\mathrm{t}_{\text {hitung }}>\mathrm{t}_{\text {tabel }}$ & $\begin{array}{l}\text { Terdapat pengaruh } \\
\text { positif dan signifikan }\end{array}$ \\
\hline
\end{tabular}

Dari tabel di atas diperoleh nilai $r_{\text {hitung }}$ sebesar 0,389 dan kemudian dibandingkan dengan $r$ tabel (dengan taraf signifikansi $\alpha$ $=0,05)$ yaitu sebesar 0,195. Hasil tersebut menunjukkan bahwa $r_{\text {hitung }}>r$ tabel, maka dapat disimpulkan bahwa ho ditolak dan $\mathrm{Ha}$ diterima (dimana $\mathrm{Ho}$ adalah tidak terdapat pengaruh orang tua terhadap minat menjadi guru Pendidikan Pancasila dan Kewarganeegaraan dan $\mathrm{Ha}$ adalah terdapat pengaruh orang tua terhadap minat menjadi guru Pendidikan Pancasila dan Kewarganegaraan).

Uji signifikansi dengan uji $\mathrm{t}$ dengan taraf signifikansi $\alpha=0,05$, diperoleh $\mathrm{t}$ hitung sebesar 5,082 dan t tabel sebesar 1,98. Karena $t$ hitung lebih besar dari $t$ tabel maka dapat disimpulkan terdapat pengaruh yang signifikan dari pengaruh orang tua terhadap minat menjadi guru Pendidikan Pancasila dan Kewarganegaraan. Besarnya kontribusi pengaruh orang tua terhadap minat menjadi guru Pendidikan Pancasila dan Kewarganegaraan dapat dilihat dengan menggunakan koefisien determinasi yaitu KD sebesar $15,16 \%$. Artinya bahwa berdasarkan hasil penelitian terdapat pengaruh orang tua sebesar 15,16\% terhadap minat menjadi guru Pendidikan Pancasila dan Kewarganegaraan pada mahasiswa Proram Studi Pendidikan Pancasila dan Kewarganegaraan angkatan ke sepuluh Fakultas Keguruan dan Ilmu Pendidikan - Universitas Pamulang.

Berdasarkan hasil penelitian diperoleh hasil perhitungan $r$ hitung sebesar 0,389. Apabila dikonsultasikan dengan nilai $r$ tabel dengan taraf signifikansi sebesar0,05 dengan jumlah sampel (n) sebanyak 106, diperoleh nilai $r$ tabel sebesar 0,195. Dari hasil tersebut dapat dilihat bahwa nilai $r$ hitung lebih besar dari nilai $r$ tabel, maka dapat dikatakan bahwa terdapat hubungan antara pengaruh orang tua terhadap minat menjadi guru Pendidikan Pancasila dan Kewarganegaraan, pada mahasiswa Prodi Pendidikan Pancasila dan Kewarganegaraan, Fakultas Keguruan dan Ilmu Pendidikan Universitas Pamulang.

Selain itu berdasarkan perhitungan didapatkan nilai t hitung sebesar 5,08 dan kemudian dibandingkan dengan nilai $t$ tabel dengan taraf signifikansi sebesar 0,05 yang mempunyai nilai sebesar 1,98 , dapat dikatakan bahwa terdapat pengaruh yang signifikan antara pengaruh orang tua dan minat menjadi guru Pendidikan 
Pancasila dan Kewarganegaraan (karena nilai t hitung hasilnya lebih besar dari nilai t tabel). Besarnya pengaruh antara orang tua dan minat menjadi guru Pendidikan Pancasila dan Kewarganegaraan dapat dilihat dari hasil perhitungan koefisien determinasi (KD), dimana dari hasil penelitian didapatkan nilai KD sebesar $15,16 \%$, yang artinya bahwa orang tua mempengaruhi minat mahasiswa program studi Pendidikan Pancasila dan Kewarganegaraan -Fakultas Keguruan dan Ilmu Pendidikan - Universitas Pamulang untuk menjadi guru Pendidikan Pancasila dan Kewarganegaraan sebesar 15,16\%.

Apabila dilihat dari besarnya nilai koefisien determinasi pengaruh dari orang tua tidak terlalu besar. Artinya bahwa pengaruh orang tua tidaklah dominan untuk menentukan minat mahasiswa proram studi di Pendidikan Pancasila dan Kewarganegaraan menjadi guru Pendidikan Pancasila dan Kewarganegaraan. Hal ini disebabkan karena ada beberapa faktor yang dapat mempengaruhi minat seseorang dalam menentukan pilihan profesinya. Dan orang tua adalah merupakan salah satu faktornya. Ada beberapa faktor yang mempengaruhi selain faktor orang tua , terbukti dengan hasil dari nilai koefisien determinasi yang tidak terlalu tinggi. Untuk mengetahui faktor yang lainnya dan berapa besar nilai pengaruhnya perlu diadakan lagi penelitian lebih lanjut.

\section{KESIMPULAN}

Berdasarkan hasil pengujian hipotesis dan analisa data, maka dapat diuraikan suatu kesimpulan sebagai berikut :

1. Uji prasyarat analisis pada penelitian ini menunjukkan bahwa populasi berdistribusi normal yang ditunjukkan dengan nilai $\mathrm{L}_{\text {hitung }}$ sebesar 0,057 dan $\mathrm{L}$ tabel sebesar 0,0861 (untuk variabel pengaruh orang tua ) dan $\mathrm{L}_{\text {hitung }}$ sebesar 0,061 dan $\mathrm{L}$ tabel sebesar 0,0861 (untuk variabel minat menjadi guru Pendidikan Kewarganegaraan). Dapat dilihat bahwa nilai $\mathrm{L}_{\text {hitung }}<\mathrm{L}_{\text {tabel }}$ sehingga dapat disimpulkan bahwa populasi berdistribusi normal. Selain itu uji prasyarat analisis juga menunjukkan bahwa model regresi berpola linear yang ditunjukkan dengan nilai $\mathrm{F}$ hitung sebesar 1,41 dan nilai $F_{\text {tabel }}$ sebesar 1,57. Dengan nilai $F$ hitung yang lebih kecil dari $F$ tabel dapat disimpulkan bahwa regresi berpola linear.

2. Terdapat hubungan antara orang tua dan minat menjadi guru Pendidikan Pancasila dan Kewarganegaraan pada mahasiswa Program Studi Pendidikan Pancasila dan Kewarganegaraan, Fakultas Keguruan dan Ilmu Pendidikan Universitas Pamulang yang ditunjukkan dengan nilai $r$ hitung sebesar 0,389, dan kemudian nilai $r$ hitung ini dibandingkan dengan nilai $r$ tabel dengan koefisien korelasi sebesar 0,05 dan n sebanyak 106, maka didapatkan nilai $\mathrm{r}_{\text {hitung }}$ lebih besar dari nilai $\mathrm{r}_{\text {tabel }}$, dimana nilai $\mathrm{r}_{\text {tabel }}$ adalah sebesar 0,195. Sehingga dapat ditarik kesimpulan bahwa terdapat korelasi atau hubungan antara orang tua dan minat 
menjadi guru Pendidikan Pancasila dan Kewarganegaraan.

3. Berdasarkan hasil penelitian didapatkan hasil dari uji signifikansi korelasi yang ditunjukkan dengan nilai atau hasil uji $t$, dimana hasil penelitian menunjukkan besarnya nilai $t$ yaitu sebesar 5,08. Hasil ini kemudian dibandingkan dengan $\mathrm{t}$ tabel dengan taraf signifikansi sebesar 0,05 didapatkan nilai $t$ tabel sebesar 1,98. Dari besarnya nilai $t_{\text {hitung }}$ yang lebih besar dari nilai $t$ tabel dapat ditarik kesimpulan bahwa terdapat pengaruh yang positif dan signifikan antara orang tua dan minat menjadi guru Pendidikan Pancasila dan Kewarganegaraan.

4. Besarnya pengaruh ditunjukkan dengan besarnya nilai koefisien determinasi, dimana pada penelitian ini diperoleh besarnya nilai Koefisien Determinasi (KD) sebesar $15,16 \%$. Hal ini menunjukkan bahwa pada program studi Pendidikan Pancasila dan Kewarganegaraan orang tua mempunyai pengaruh terhadap minat menjadi guru Pendidikan Kewarganegaraan sebesar $15,16 \%$.

\section{REFERENSI}

Abros, A, R. 1999. Psikologi Pendidikan. Yogyakarta: Tiara Wacana.

Arikunto, S. 2013. Prosedur Penelitian. Jakarta: Rineke Cipta.

Crow, C. 2005. Psikologi Pendidikan. Yogyakarta: Tiara Wacana.
Dalyono. 2015. Psikologi Pendidikan. Jakarta: Rineke Cipta.

Hamalik, O. 2010. Psikologi Belajar dan Mengajar. Bandung: Sinar Baru Algensindo.

Helmawati. 2014. Pendidikan Keluarga. Bandung: Remaja Rosdakarya.

Mulyasa, E. 2009. Menjadi Guru Profesional. Bandung: Remaja Rosdakarya.

Nuryani, T. 2014. Hubungan Minat Menjadi Guru dan Sumber Informasi Dunia Kerja dan Kesiapan Mahasiswa menjadi Guru Profesional pada Mahasiswa Jurusan PKN di Perguruan Tinggi di DIY. Skripsi. UNY.

Purwanto, N. 2010. Psikologi Pendidikan. Bandung: Remaja Rosdakarya

Pusat Bahasa Depdiknas. 2002. Kamus Besar Bahasa Indonesia (Edisi ketiga). Jakarta: Balai Pustaka.

Slamento. 2015. Belajar dan Faktor-faktor yang mempengaruhi. Jakarta: Rineke Cipta

Sugiyono. 2014. Metode Penelitian Kuantitatif Kualitatif dan $R \quad \mathcal{E} D$. Bandung: Alfabeta

Supardi. 2013. Aplikasi Statistika dalam Penelitian. Jakarta: Change Publication.

Syah, M. 2005. Psikologi Pendidikan Suatu Pendekatan Baru. Bandung: Remaja Rosdakarya.

Undang Undang Dasar Negara Republik Indonesia Tahun 1945.

Undang Undang No 14 Tahun 2005 Tentang Guru dan Dosen.

Usman, M, U. 2013. Menjadi Guru Profesional. Bandung: Remaja Rosdakarya. 